\title{
ターゲット計測によるレーザスキャナのキャリブレーション
}

\section{Calibration Method of Laser Scanner by Target Measurement}

\author{
平岡 透* \\ Toru HIRAOKA
}

\begin{abstract}
There are several kinds of laser scanners available for two-dimensional and three-dimensional measurement of object shapes, and there are some methods for setting the measurement devices in those laser scanners. Among those methods, calibration techniques are important for their practical use. I propose, in this technical report, some calibration methods of a laser scanner by measuring a target object with simple geometric shapes without using special machineries.
\end{abstract}

Keywords：レーザスキャナ, キャリブレーション, ターゲット計測, 最小二乗法

\section{1.はじめに}

レーザスキャナは，レーザを対象物に照射すること によって対象物との距離を高精度に且つ即時に計測す ることができる機器である。このため，車両や台車等 の移動可能な装置（以下，計測装置）にレーザスキャ ナを搭載して，周辺環境の状沉を計測するということ が現在良く行われている（趙ら，2002；Zhao et al., 2003 ; 平岡ら，2007）。このとき，レーザスキャナと計 測装置に搭載されている GPSやカメラ等の各種機器 との相対的な位置関係が必要となる場合がある。例之 ば，レーザスキャナより取得した点群データを GPS より取得した軌跡データ上にマッピングする場合や， レーザスキャナより取得した点群データから作成され たポリゴンデータにカメラより取得した画像を自動で テクスチャマッピングする場合等である。

レーザスキャナと各種機器間の相対的な位置関係を 求めるためには，レーザスキャ十の位置や方向を求め るキャリブレーションが必要となる。レーザスキャナ には 2 次元的な計測が可能なもの（以下，2 次元レー

*株式会社ゼンリン

干804-0003 福岡県北九州市戸烟区中原新町3-1

「写真測量とりモートセンシング」VOL. 47, NO. 4, 2008
ザスキャナ）と 3 次元的な計測が可能なもの（以下， 3 次元レーザスキャナ）があり，またレーザスキャナ を計測装置に設置する場合にも多数の仕方があるた め，レーザスキャナのキャリブレーションにも多数の 方法が存在することとなる (平岡, 2008)。そこで, 本 技術報告では特に，2次元レーザスキャナの計測可能 な平面が計測装置の進行方向と平行になるように計測 装置の前方に設置して，2次元レーザスキャナの平面 位置 $(X Y)$ と $Z$ 軸に対する回転の方向を求めるキャ リブレーション（以下，キャリブレーション（I ））の 方法を提案し, 実験を通してその有効性を示す。また, 理論のみであるが， 3 次元レーザスキャナの位置 $(X Y Z)$ と $X Y Z$ 軸それぞれに対する回転の方向を求 めるキャリブレーション（以下，キャリブレーション (II)）の方法も提案する。

関連研究として，レーザスキャナのキャリブレー ションには，トータルステーションを用いて直接レー ザスキャナの位置を観測する方法, 不可視のレーザを 直接見ることのできるIRスコープを用いる方法, レーザが当たるとビープ音を発するCobit を用いる方 法 $(2004$, 長井ら)，4点以上の基準点に設置した反射 シ一トを用いる方法（2005，氏家）等が提案されてい る。本提案法は, トータルステーション, IR スコープ, Cobit, 反射シート等の特別な機器を使用せず，幾何学 的に単純なターゲットを計測することによってキャリ 
ブレーションを行うものである。

\section{2. 方 法}

以下に, キャリブレーション( I ) とキャリブレー ション(II)の方法をそれぞれ示す。

\section{1 キャリブレーション(I)の方法}

まず，平らな地面に計測装置を置き，水準器を用い て 2 次元レーザスキャナが地面と平行となるように設 置する。また， 2 次元レーザスキャナの計測原点の高 さは，2次元レーザスキャナの内部構造が設計図で 分っているため, 2 次元レーザスキャ十の底部から計 測原点までの高さに，2次元レーザスキャ十の底部ま でを金尺で計測した高さを加えることで求めることが できる。

次に, 平らな地面に置いた横幅の長さ $r$ が定の面 を持つターゲット (I) (図 1 参照)を 2 次元レーザス キャナで計測する。取得された点群データからター ゲット (I)の凸部の角と考之られる両端の点 $P_{A}, P_{B}$ と 2 次元レーザスキャナの計測原点 $P_{o}$ との距離 $l_{A}$, $l_{B}$, 点 $P_{A}$ と計測原点 $P_{O}$ を結ぶ直線と点 $P_{B}$ と計測原 点 $P_{o}$ を結ぶ直線のなす角度 $\theta$ を取得する (図 2 参 照)。点 $P_{A}, P_{B}$ はユーザが手動で選択する。点 $P_{A}, P_{B}$ は, 計測距離及び計測角度が離散的であるために生じ る量子化誤差によって，必ずしもターゲット（I）の角 となる保証はない。ここでは, 以下の計算を単純にす るため, ターゲット (I )の角である理想的な点 $P_{A^{\prime}}, P_{B^{\prime}}$ の座標值をそれぞれ $(0,0),(r, 0)$ とする。計測された 点 $P_{A}, P_{B}$ の座標値をそれぞれ $\left(x_{A}, y_{A}\right),\left(x_{B}, y_{B}\right)$, 夕一 ゲット (I)の凸部の点 $P_{A}$ と点 $P_{B}$ の間の点 $P_{i}(i=1$, $2, \cdots, m)$ の座標值を $\left(x_{i}, y_{i}\right)$, 計測原点 $P_{o}$ の座標值を $\left(x_{0}, y_{0}\right)$ とする。ターゲット ( I )の凸部で計測された 点 $P_{i}$ も, 計測距離が離散的であるために量子化誤差が 生じ, 必ずしもターゲット（I）の表面上の点となる保 証はない。そこで, 点 $P_{A}, P_{B}, P_{i}$ を平行移動及び回転さ せて, 点 $P_{A}, P_{A^{\prime}}$ 間の距離, 点 $P_{B}, P_{B^{\prime}}$ 間の距離, 点 $P_{i}$ を $X$ 軸に下ろした垂線の長さの和が最小となるよう に平行移動量 $(\Delta x, \Delta y)$ 及び回転量 $\Delta \theta$ を決定する (図 3 及び式(1)参照)。

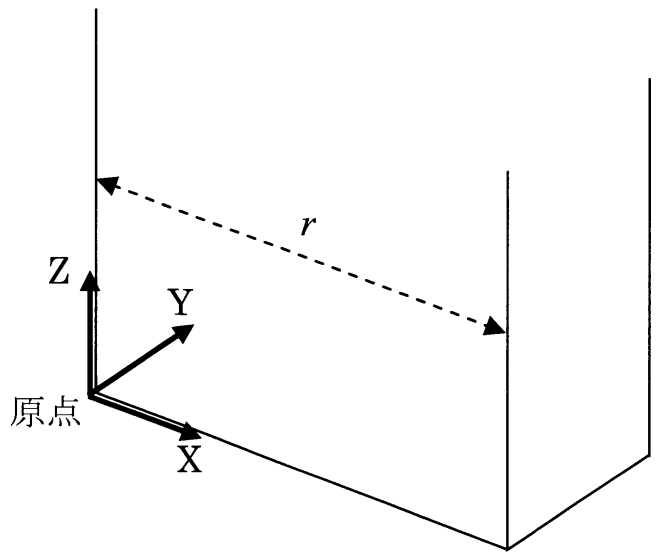

図 1 ターゲット (I)

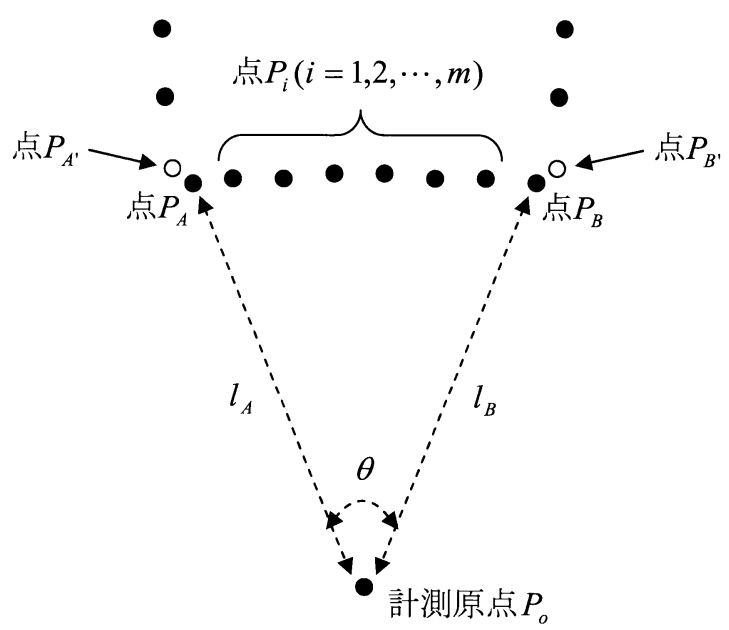

図2 ターゲット(I )の計測データ

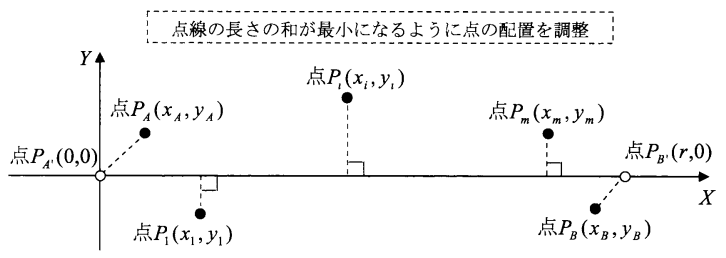

図 3 点 $\boldsymbol{P}_{A}, \boldsymbol{P}_{B}, \boldsymbol{P}_{i}$ の位置の推定

$$
\begin{aligned}
& \min _{\Delta x, \Delta y, \Delta \theta} \sum_{i=1}^{m}\left(x_{i} \sin \Delta \theta+y_{i} \cos \Delta \theta+\Delta y\right)^{2} \\
& \quad+\left(x_{A} \cos \Delta \theta-y_{A} \sin \Delta \theta+\Delta x\right)^{2} \\
& \quad+\left(x_{A} \sin \Delta \theta+y_{A} \cos \Delta \theta+\Delta y\right)^{2} \\
& \quad+\left(\left(x_{B} \cos \Delta \theta-y_{B} \sin \Delta \theta+\Delta x\right)-r\right)^{2} \\
& \quad+\left(x_{B} \sin \Delta \theta+y_{B} \cos \Delta \theta+\Delta y\right)^{2}
\end{aligned}
$$


式(1)を $\Delta a=\cos \Delta \theta, \Delta b=\sin \Delta \theta$ として式(2)のように 変換する。

$$
\begin{aligned}
& \min _{\Delta x, \Delta y, \Delta a, \Delta b} \sum_{i=1}^{m}\left(\Delta b x_{i}+\Delta a y_{i}+\Delta y\right)^{2} \\
& +\left(\Delta a x_{A}-\Delta b y_{A}+\Delta x\right)^{2}+\left(\Delta b x_{A}+\Delta a y_{A}+\Delta y\right)^{2} \\
& +\left(\left(\Delta a x_{B}-\Delta b y_{B}+\Delta x\right)-r\right)^{2}+\left(\Delta b x_{B}+\Delta a y_{B}+\Delta y\right)^{2}
\end{aligned}
$$

Subject to $\Delta a^{2}+\Delta b^{2}=1$

式(2)の解は式(3)の反復解法で求める。式(3)は式(2)を $\Delta x, \Delta y, \Delta a, \Delta b$ で偏微分した結果をイコール 0 とし て整理することで求まる。

$\Delta x^{(s+1)}=-\left(\Delta a^{(s)} x_{A}-\Delta b^{(s)} y_{A}+\Delta a^{(s)} x_{B}-\Delta b^{(s)} y_{B}-r\right) / 2$

$\Delta y^{(s+1)}=-\frac{\sum_{i=1}^{m}\left(\Delta b^{(s)} x_{i}+\Delta a^{(s)} y_{i}\right)+\Delta b^{(s)} x_{A}+\Delta a^{(s)} y_{A}+\Delta b^{(s)} x_{B}+\Delta a^{(s)} y_{B}}{m+2}$

$\Delta a^{(s+1)}=-\frac{\sum_{i=1}^{m}\left(\Delta b^{(s)} x_{i} y_{i}+\Delta y^{(s)} y_{i}\right)+\Delta x^{(s)} x_{A}+\Delta y^{(s)} y_{A}+\Delta x^{(s)} x_{B}+\Delta y^{(s)} y_{B}-r x_{B}}{\sum_{i=1}^{m} y_{i}^{2}+x_{A}^{2}+y_{A}^{2}+x_{B}^{2}+y_{B}^{2}}$

$\Delta b^{(s+1)}=-\frac{\sum_{i=1}^{m}\left(\Delta a^{(s)} x_{i} y_{i}+\Delta y^{(s)} x_{i}\right)+\Delta y^{(s)} x_{A}-\Delta x^{(s)} y_{A}+\Delta y^{(s)} x_{B}-\Delta x^{(s)} y_{B}+r y_{B}}{\sum_{i=1}^{m} x_{i}^{2}+x_{A}^{2}+y_{A}^{2}+x_{B}^{2}+y_{B}^{2}}$

$\Delta a^{(s+1)}=\Delta a^{(s+1)} / \sqrt{\Delta a^{(s+1) 2}+\Delta b^{(s+1) 2}}$

$\Delta b^{(s+1)}=\Delta b^{(s+1)} / \sqrt{\Delta a^{(s+1)^{2}}+\Delta b^{(s+1)^{2}}}$

ここで, $s$ は反復回数であり, 初期值を $\Delta x^{(0)}=0, \Delta y^{(0)}$ $=0, \Delta a^{(0)}=1, \Delta b^{(0)}=0$ として, 収束するまで繰り返す。 反復解法で局所的な解に収束しないように, 点 $P_{A}, P_{B}$, $P_{i}$ の平行移動及び回転前の座標值は, 点 $P_{A}, P_{B}$ が $X$ 軸上に, 且つ点 $P_{A}, P_{A^{\prime}}$ 間の距離と点 $P_{B}, P_{B^{\prime}}$ 間の距離 が等しくなるように配置する (図 4 参照)。

最後に, 求めた平行移動量 $(\Delta x, \Delta y)$ 及び回転量 $\Delta a$, $\Delta b$ 上り, 平行移動及び回転後の計測原点 $P^{\prime}$ 。の座標 值 $\left(x_{o}^{\prime}, y_{o}^{\prime}\right)$ を求め, 視点の位置とする。

$x_{o}^{\prime}=\Delta a x_{o}-\Delta b y_{o}+\Delta x$

$y_{o}^{\prime}=\Delta b x_{o}-\Delta a y_{o}+\Delta y$

同様に, 注視点 $P_{g}^{\prime}$ の座標値 $\left(x_{g}^{\prime}, y_{g}^{\prime}\right)$ を求める。注視点 $P_{g}^{\prime}$ は, 2 次元レーザスキャナの構造上, 順次得られた

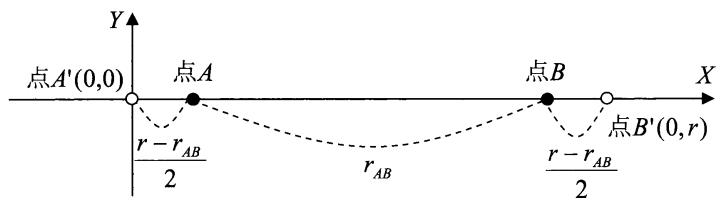

図 4 点 $\boldsymbol{P}_{A}, \boldsymbol{P}_{B}, \boldsymbol{P}_{i}$ の平行移動及び回転前の座標值の設定 条件
総計測点数の真ん中の点である。つまり，2次元レー ザスキャナの平面位置 $(X Y)$ とは視点 $P^{\prime}$ 。の位置であ $\eta, Z$ 軸に対する回転の方向とは視点 $P^{\prime} 。$ と注視点 $P^{\prime}{ }_{g}$ とを結ぶ直線と $X$ 軸のなす角である。

キャリブレーションを行う上での計測装置とター ゲット (I ) との最適な位置関係等について考える。䛊 差要因として, 計測距離及じ計測角度が離散的であり, このために量子化䛊差が生じる。また， 2 次元レーザ スキャナとターゲット (I ) との距離が大きい程, 2 次 元レーザスキャナで計測される点間距離が大きくな ク，2 次元レーザスキャナのキャリブレーションの精 度が低下寸る。その他の䛊差要因として, レーザ光の スポット径やレーザ光の対象物への入射角, 対象物の 反射率等がある。レーザ光のスポット径は, 距離と共 に広がり，またレーザ光が斜めに対象物に入射すると 細長い楕円となるため, 䛊差が大きくなる。それから， 対象物の反射率が大きいと計測距離が短くなることが 一般に知られている。これらの誤差要因の影響を少な くするためには，2 次元レーザスキャナと夕ーゲット （I）の距離を短くすること, ターゲット ( I )へのレー ザ光の入射角を小さくすること, ターゲット（I）の反 射率は均一で鏡や金属等のような反射率の大きいもの は使用しないことが望ましい。

\section{2 キャリブレーション(II)の方法}

まず， 3 次元レーザスキャナを計測装置に設置する。 次に, 横幅の長さ $r$, 縦幅の長さ $s$ の長方形の面を持つ ターゲット（II）（図５参照）を 3 次元レーザスキャナ で計測する。取得された点群データからターゲット (II)の凸部の長方形の面の角と考えられる四隅の点 $P_{A}, P_{B}, P_{C}, P_{D}$ の座標值をそれぞれ $\left(x_{A}, y_{A}, z_{A}\right),\left(x_{B}\right.$, $\left.y_{B}, z_{B}\right),\left(x_{C}, y_{C}, z_{C}\right),\left(x_{D}, y_{D}, z_{D}\right)$, 四隅の点 $P_{A}, P_{B}, P_{C}$, $P_{D}$ 以外のターゲット $(\mathrm{II})$ の凸部の点 $P_{i}(i=1,2, \cdots$, $m)$ の座標値を $\left(x_{i}, y_{i}\right)$ とする (図 6 参照)。ここでは, 以下の説明を簡単にするため, ターゲット (II)の凸部 の長方形の面の四隅の理想的な角の点 $P_{A^{\prime}}, P_{B^{\prime}}, P_{C^{\prime}}$, $P_{D^{\prime}}$ の座標値をそれぞれ $(0,0,0),(0,0, s),(r, 0, s),(r$, $0,0)$ とする。

点 $P_{A}, P_{B}, P_{C}, P_{D}, P_{i}$ を平行移動及び回転させて, 点 $P_{A}, P_{A^{\prime}}$ 間の距離, 点 $P_{B}, P_{B^{\prime}}$ 間の距離, 点 $P_{C}, P_{C^{\prime}}$ 間の 距離, 点 $P_{D}, P_{D^{\prime}}$ 間の距離, 点 $P_{i}$ を $X Z$ 平面上に下ろ した垂線の長さの和が最小となるように平行移動量 $(\Delta x, \Delta y, \Delta z)$ 及び回転量 $(\Delta \omega, \Delta \phi, \Delta x)$ を決定する。3 


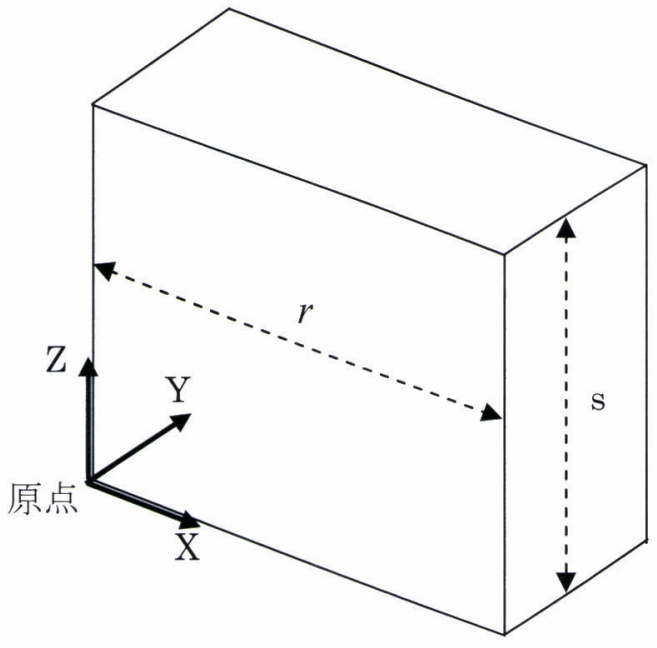

図 5 ターゲット(II)

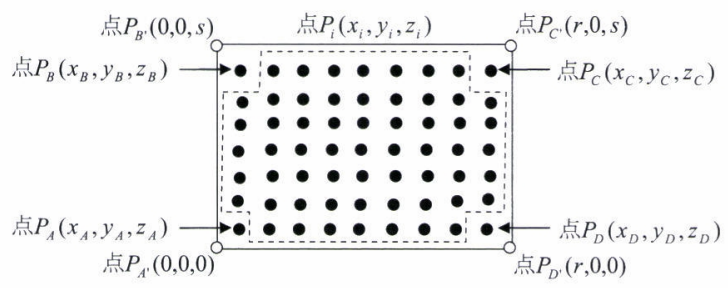

図 6 ターゲット (II)の計測データ

次元空間に㧍ける座標の回転には才イラ一角を用い る。点 $P_{A}, P_{B}, P_{C}, P_{D}, P_{i} \sigma$ 平行移動及び回転後の点 $\left.P_{A}^{\prime}, P_{B}^{\prime}, P^{\prime}{ }_{C}, P^{\prime}{ }_{D}, P^{\prime}{ }_{i} \sigma\right)$ 座標值をそれぞれ $\left(x^{\prime}{ }_{A}, y^{\prime}{ }_{A}\right.$, $\left.z_{A}^{\prime}\right),\left(x_{B}^{\prime}, y_{B}^{\prime}, z_{B}^{\prime}\right),\left(x_{C}^{\prime}, y_{C}^{\prime}, z_{C}^{\prime}\right),\left(x_{D}^{\prime}, y_{D}^{\prime}, z_{D}^{\prime}\right),\left(x_{i}^{\prime}\right.$, $\left.y^{\prime}{ }_{i}, z^{\prime}{ }_{i}\right)$ として, 式(5)が成り立つ平行移動量 $(\Delta x, \Delta y$, $\Delta z)$ 及び回転量 $(\Delta \omega, \Delta \phi, \Delta x)$ を求める。式(5)の)解は, 式(3)と同様な反復解法で求めることができる。

$$
\begin{aligned}
& \min _{\Delta x, \Delta y, \Delta z, \Delta \omega, \Delta \phi, \Delta \kappa} \sum_{i=1}^{m} y_{i}^{\prime 2}+\left(x_{A}^{\prime 2}+y_{A}^{\prime 2}+z_{A}^{\prime 2}\right) \\
& +\left(x_{B}^{\prime 2}+y_{B}^{\prime 2}+\left(z_{B}^{\prime}-s\right)^{2}\right) \\
& +\left(\left(x_{C}^{\prime}-r\right)^{2}+y_{C}^{\prime 2}+\left(z_{C}^{\prime}-s\right)^{2}\right) \\
& +\left(\left(x_{D}^{\prime}-r\right)^{2}+y_{D}^{\prime 2}+z_{D}^{\prime 2}\right)
\end{aligned}
$$

最後に, 求めた平行移動量 $(\Delta x, \Delta y, \Delta z)$ 及び回転量 $(\Delta \omega, \Delta \phi, \Delta x)$ より，平行移動及び回転後の計測原点の 座標值を求め, 視点の位置とする。同様に, 注視点の 座標值を求める。注視点は，3次元レーザスキャナの 構造上, 順次得られた総計測点数の真ん中の点である。 つまり，3 次元レーザスキャナの位置 $(X Y Z)$ とは視 点の位置であり， $X$ 軸に対する回転の方向とは視点と 注視点を結ぶ直線 (以下, 直線 $V G$ ) を $Y Z$ 平面に投
影後の直線と $Z$ 軸のなす角であり， $Y$ 軸に対する回 転の方向とは直線 $V G$ を $Z X$ 平面に投影後の直線と $X$ 軸のなす角であり， $Z$ 軸に対する回転の方向とは直 線 $V G$ を $X Y$ 平面に投影後の直線と $Y$ 軸のなす角 である。

\section{3. 実験}

キャリブレーション（Ｉ）について実験を行う。実験 で使用した 2 次元レーザスキャナはSICK 社製 LMS200 (計測可能角度 180 度, 角分解能 0.5 度, 距離分 解能 $0.01 \mathrm{~m}$, システム䛊差 $\pm 0.04 \mathrm{~m}$ ) であり, 水準器 (夕 ジマツール社製 POK3-23) を用いて地面と平行となる ように計測装置に設置した。SICK 社製 LMS200のシ ステム䛊差とは，距離測定範囲と反射率において考え られる全ての䛊差の合計值である（LMS200付属の技 術資料参照)。困 7 のよう計測装置にはDVカメラ (Canon 社製 DM-IXY DV M；画面サイズ640×480 pixl) も取り付けた。DVカメラを計測装置に搭載した 理由は， 2 次元レーザスキャナと DVカメラを同時に キャリブレーションの操作を行い, 2 次元レーザス キャナと DVカメラの相対的な位置関係を複数の位 置で求めることによって，2次元レーザスキャ十の キャリブレーションの性能を評価するためである。 DV カラのキャリブレーションには，内部標定及び 外部標定を同時に行える高精度な井本ら（2003）の方 法を用いた。ターゲット (I ) として, 四 8 に示す部

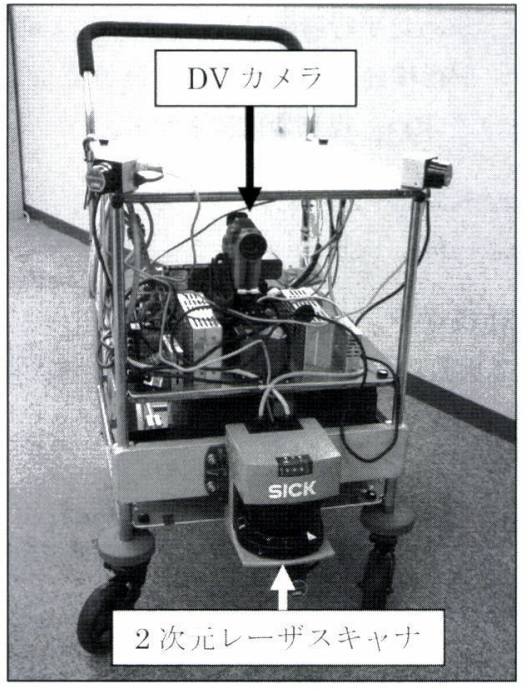

図 7 実験で使用した計測装置 

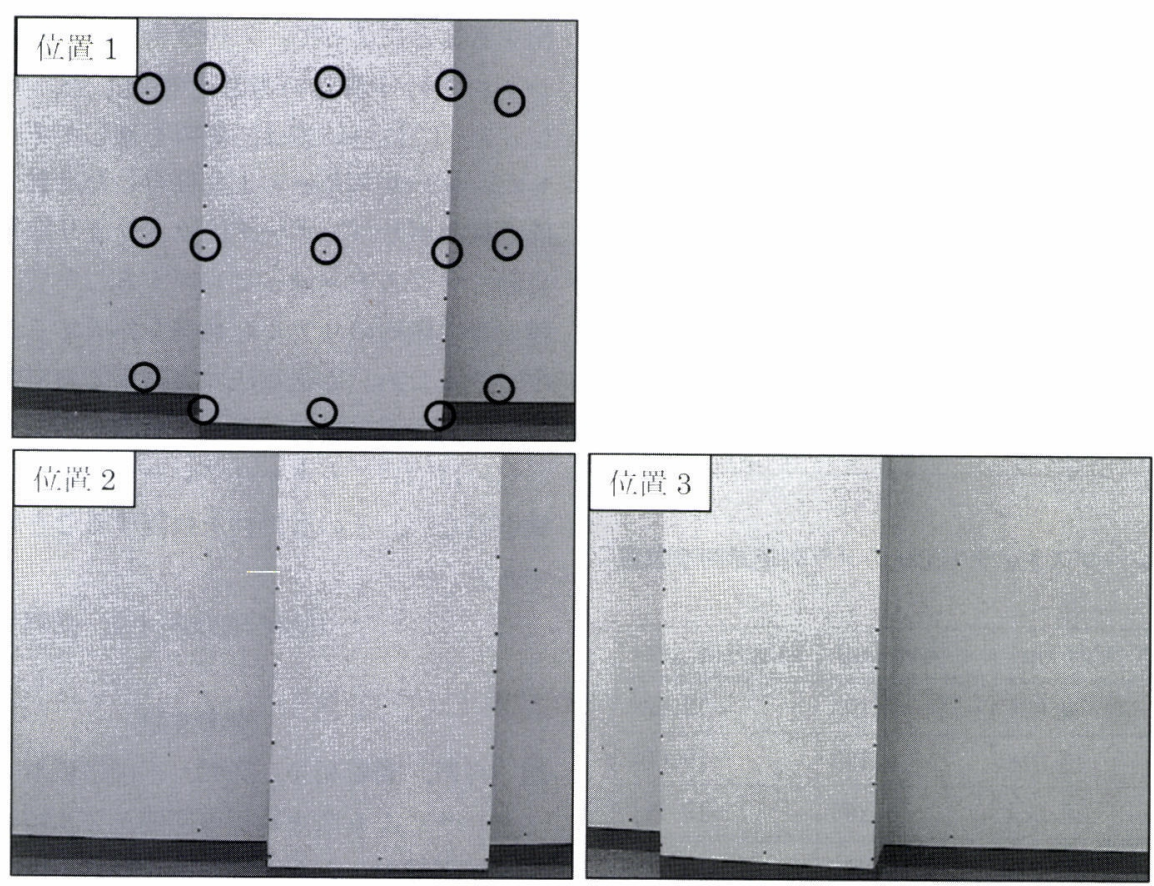

図８実験で使用したターゲット（I）

の横幅の長さが $0.586 \mathrm{~m}$ で反射率がそれ程大きくない ものを用いた。罒8の位置1の図の丸印で囲まれた15 点は, DV カメラのキャリブレーションで使用した標 定点である。これらの標定点の画像上の位置は, 手動 で取得した。

2 次元レーザスキャナのキャリブレーションの性能 を向上されるためには，2次元レーザスキャナと夕ー ゲット（I）の距離を短くすること, ターゲット（I）へ のレーザ光の入射角を小さくすることが必要である。 また, DVカメラのキャリブレーションの性能を向上 されるためには, 取得した画像に標定点が全体に且つ 均一に映っている方が良い。これらのことを考慮して， 図 9 のよjにターゲット ( I ) から約 $2.0 \mathrm{~m}$ 離れた $3 つ$

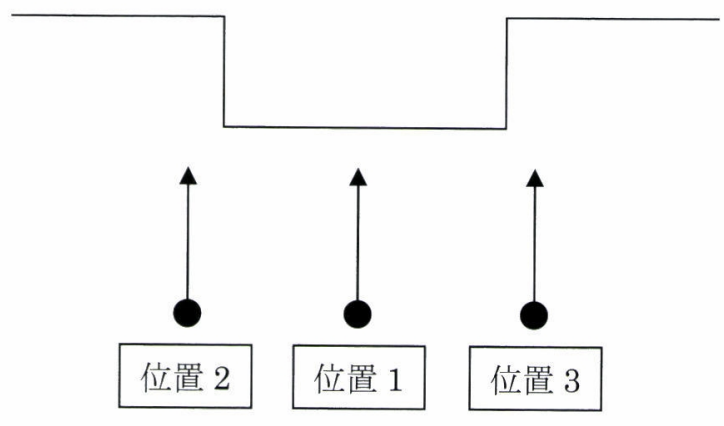

図 9 ターゲット(I) を計測した位置（上面図）
の位置に計測装置を置いて実験を行った。四 9 の位置 1 で取得した画像が図 8 の位置 1 の画像である。同様 に, 四 9 の位置 2 と図 8 の位置 2 , 図 9 の位置 3 と図

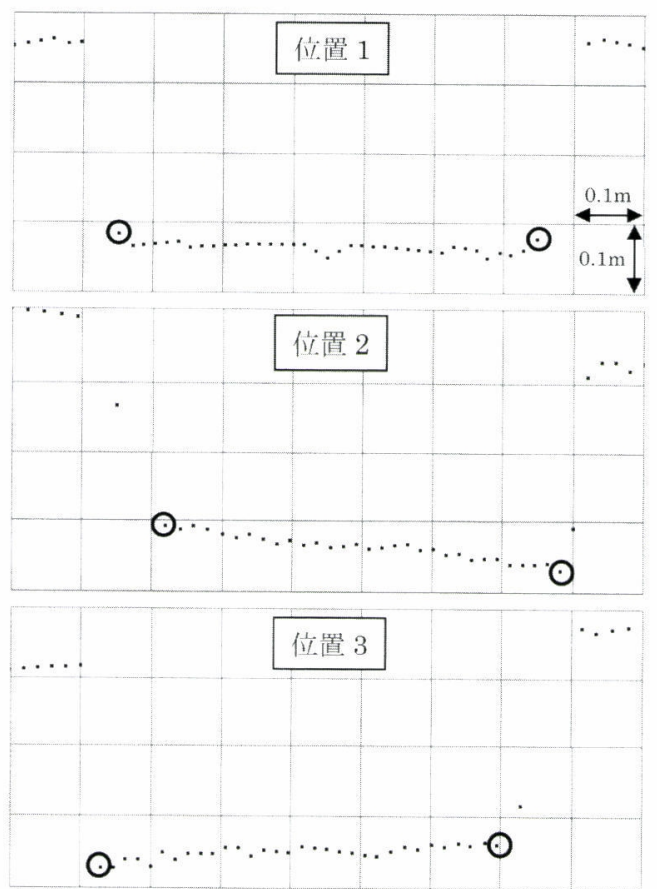

図10 各位置から計測したターゲット ( I ) の点群データ 
表 1 DV カメラのキャリブレーションの誤差

\begin{tabular}{|c|c|c|c|c|}
\hline 位置 & 誤差の種類 & $\begin{array}{c}X \text { 方向 } \\
(\mathrm{m})\end{array}$ & $\begin{array}{c}Z \text { 方向 } \\
(\mathrm{m})\end{array}$ & $\begin{array}{c}\text { 距離 } \\
(\mathrm{m})\end{array}$ \\
\hline \multirow{2}{*}{ 位置 1} & 平均誤差 & 0.003 & 0.003 & 0.005 \\
\hline & 最大誤差 & 0.011 & 0.011 & 0.016 \\
\hline \multirow{2}{*}{ 位置 2} & 平均誤差 & 0.006 & 0.003 & 0.006 \\
\hline & 最大誤差 & 0.016 & 0.012 & 0.020 \\
\hline \multirow{2}{*}{ 位置 3} & 平均誤差 & 0.005 & 0.004 & 0.006 \\
\hline & 最大誤差 & 0.013 & 0.013 & 0.019 \\
\hline
\end{tabular}

表 22 次元レーザスキャナと DV カメラの相対的な位置 関係

\begin{tabular}{|c||r|r|r|}
\hline & $X$ 方向 $(\mathrm{m})$ & $Y$ 方向 $(\mathrm{m})$ & 回転方向 $($ 度 $)$ \\
\hline \hline 位置 1 & 0.021 & -0.193 & -19.609 \\
\hline 位置 2 & 0.016 & -0.199 & -19.608 \\
\hline 位置 3 & 0.024 & -0.208 & -19.711 \\
\hline \hline 最大較差 & 0.008 & 0.015 & 0.103 \\
\hline
\end{tabular}

8 位置 3 が対応する。

まず，DVカメラの画像をターゲット（I）のモデル にテクスチャマッピングして得られた標定点の位置と 実空間上での標定点の位置との差の絶対值を求めるこ とで，DVカメラのキャリブレーションの性能を評価 した。この結果を表 1 に示す。図 9 に示す全ての位置 で距離の平均誤差が $0.006 \mathrm{~m}$ 以内, 最大誤差が $0.020 \mathrm{~m}$ 以内となり，2 次元レーザスキャナのキャリブレー ションの性能を評価する基準として使用する上で十分 有効な DVカメラのキャリブレーションが行えたと 判断した。

次に, 実験で得られた 2 次元レーザスキャナと DV カメラの相対的な位置関係 (平面位置 $(X Y), Z$ 軸に 対する回転の力向）の結果を表 2 に示す。 3 つの位置 の組合せの中での最大較差は, $X$ 方向で $0.008 \mathrm{~m}, Y$ 方 向で $0.015 \mathrm{~m}$, 回転方向で 0.103 度であり, 良好な結果が 得られたと考えられる。参考のため, 図10に実際に図 9 の各位置からターゲット (I) を計測した点群データ を示す。図10の円内の点がターゲット（I）の凸部の角 として選択した点である。

\section{4. 結 論}

本技術報告では，幾何学的に単純なターゲットを計 $-58-$
測することによって，レーザスキャナのキャリブレー ションを行う新しい方法を提案した。キャリブレ一 ション（I）については, 実験を通してその有効性を示 した。レーザスキャナより取得した点群デー夕から作 成されたポリゴンデータにカメラより取得した画像を 自動でテクスチャマッピングすることで，地下街や駅 構内等の屋内のリアルな地困を作成すること等を検討 中であるため, 本提案法の実利用での有効性を検証す ることが今後の課題である。また，キャリブレーショ ン（II）についてもキャリブレーション（I）と同様な実 験を行ない，その有効性を検証することも今後の課題 である。

(受付日2008.4.1, 受理日2008.7.15)

\section{参考文献}

趙 卉菨, 柴崎亮介, 2002. 車両搭載型レーザレンジ センサによる 3 次元都市空間モデルの自動構築, 第 8 回画像センシングシンポジウム, pp.121-126.

H. Zhao and R. Shibasaki, 2003. A Vehicle-borne Urban 3D Acquisition System using Single-row Laser Range Scanners, IEEE Trans. SMC Part B : Cybernetics, vol. 33, no. 4.

平岡 透, 若松浩二, 2007. 屋内地図作成のための 3 次元地図点群データからの 2 次元地図ベクトルデー 夕の作成, 写真測量とリモートセンシング, vol. 46, no. 4 , pp.66-70.

平岡 透, 2008. レーザスキャナのキャリブレーショ ン装置及びキャリブレーション方法, 特許出願, 特 願2008-003737.

長井正彦，柴崎亮介，マナンダ・ディネッシュ， 2004.

“Cobit”によるレーザスキャナのキャリブレーショ ン手法に関する研究, 日本写真測量学会平成16年度 年次講演会発表論文集, pp. $1-4$.

氏家康二，2005.レーザスキャナを用いたオブジェク トマッチングによる地すべり変位追跡, 高知工科大 学平成16年度修士論文。

井本治孝, 服部 進, 秋本圭一, 2003. 2 次元夕ーゲッ 卜場によるカメラキャリブレーション, 日本写真測 量学会平成15年度年次学術講演会論文集, pp.37-40. 秋本圭一, 服部 進, 井本治孝, 2001. ディジタル画 像計測法を用いた精密工業計測, 電子情報通信学会 誌, vol. J84-D-II, No. 7, pp.1299-1309. 